\title{
Review
}

\section{Mapping mentor teachers' roles in mentoring dialogues}

\author{
Paul Hennissen ${ }^{\mathrm{a}}$, Frank Crasborn ${ }^{\mathrm{a}, *}$, Niels Brouwer ${ }^{\mathrm{b}}$, \\ Fred Korthagen ${ }^{c, d}$, Theo Bergen ${ }^{b, e}$ \\ a Department of Teacher Education, Fontys University of Applied Sciences, Sittard, The Netherlands \\ ${ }^{\mathrm{b}}$ ILS Graduate School of Education, Radboud University, Nijmegen, The Netherlands \\ ${ }^{\mathrm{c}}$ Vrije Universiteit, Amsterdam, The Netherlands \\ ${ }^{\mathrm{d}}$ Utrecht University, Utrecht, The Netherlands \\ e Eindhoven School of Education, University of Technology, Eindhoven, The Netherlands
}

Received 22 March 2007; received in revised form 14 September 2007; accepted 4 January 2008

\begin{abstract}
This literature study deals with the issue of how to conceptualize the supervisory behaviour of mentor teachers in mentoring dialogues by systematically examining empirical literature on key aspects of mentor teachers' behaviour during dialogues with prospective teachers. From the findings a model is derived which can be used to study mentor teachers' behaviour in mentoring dialogues. The model may be helpful in the further development of the quality of mentor teachers' behaviour in mentoring dialogues. (C) 2008 Elsevier Ltd. All rights reserved.
\end{abstract}

Keywords: Mentoring; Mentor teacher; Mentor teachers' roles; Mentoring dialogue; Supervisory behaviour

\section{Contents}

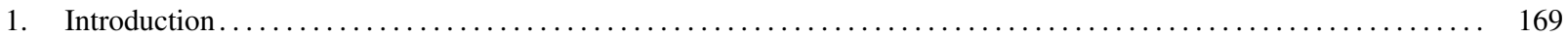

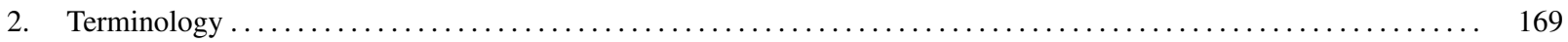

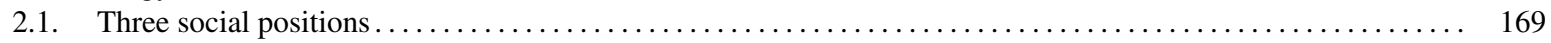

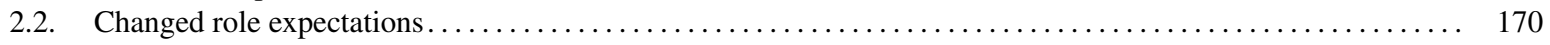

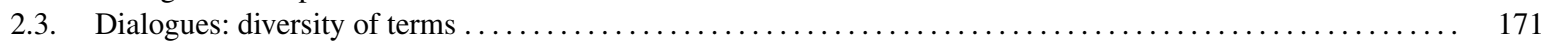

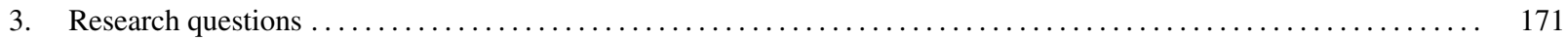

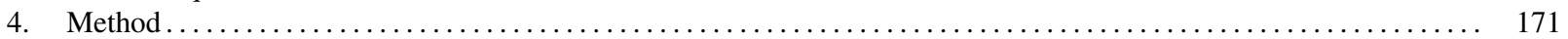

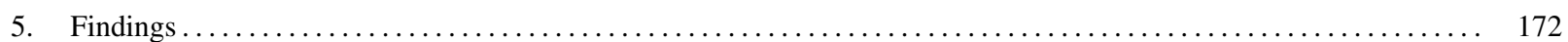

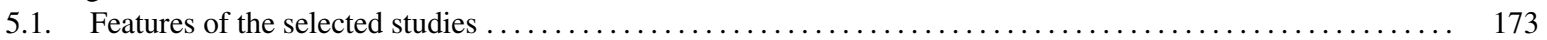

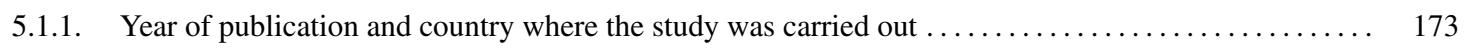

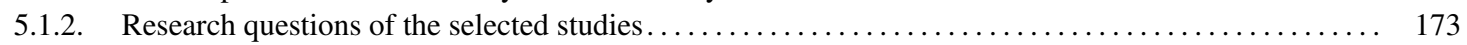

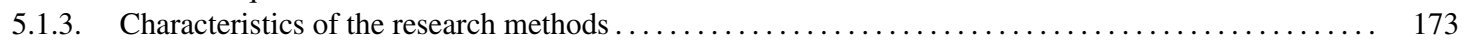

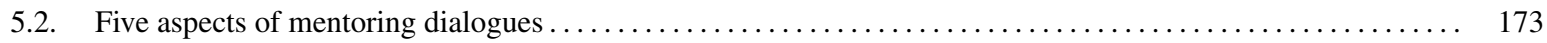

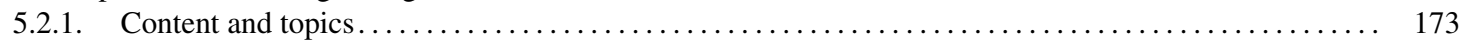

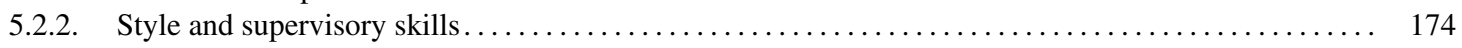

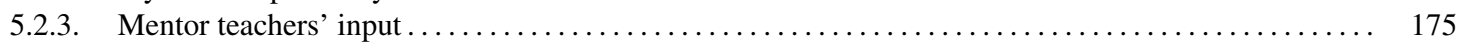

\footnotetext{
* Corresponding author at: Department of Teacher Education, Fontys University of Applied Sciences, PO Box 558, 6130 AN Sittard, The Netherlands. Tel.: +31 8778 79568; fax: +31 877875500 .

E-mail address: f.crasborn@ fontys.nl (F. Crasborn).
} 


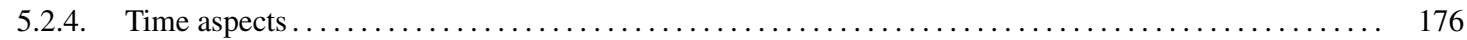

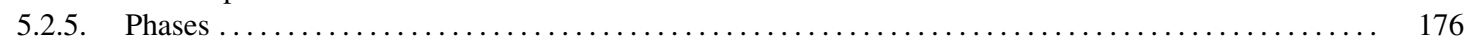

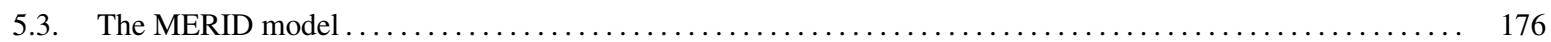

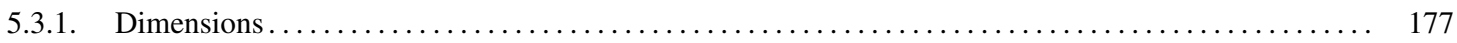

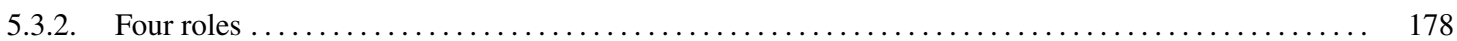

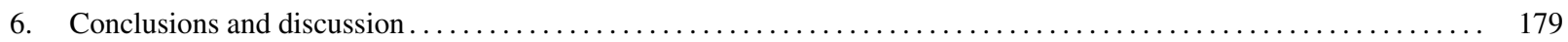

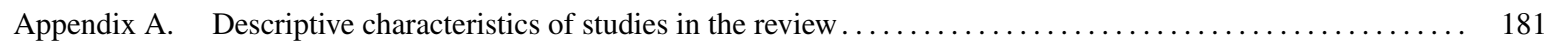

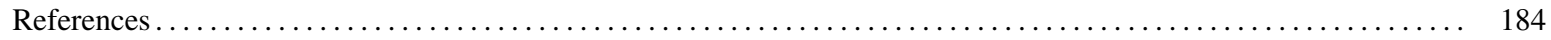

\section{Introduction}

When Odysseus went into battle with the Trojans during the Trojan War, he left his son Telemachus behind and placed him under the wing of a personal supervisor and companion. This "mentor" was at the same time a father-figure, a teacher, a role model, an advisor and guide. The versatility of the mentor role from classical times is reflected in the wide variety of terms and concepts found in the description of the mentor in professional training such as teacher education. The role of the mentor teacher as it exists nowadays in teacher education in the Western world has over the last decades gained importance, more recently in connection with a trend towards school-based teacher education. In teacher training, there is now more emphasis placed on the school as a learning environment (Brouwer, 2007; MantleBromley, 2003; Smith, 2003). This shift can be attributed to four factors: increasing scientific recognition of the value of learning in the workplace (Eraut, 2000), criticism of the relevance of theory in teacher education programmes as a preparation for practice (Koetsier \& Wubbels, 1995), the teacher shortages faced by many countries (Stijnen, 2003), and the idea that teacher training is less expensive if it is done in the workplace (Caldwell \& Carter, 1993).

One essential condition for teachers to learn in the workplace is the availability of effective guidance by and cooperation with a mentor teacher whose supervisory approach matches the learning needs of the prospective teacher (Bennett \& Carré, 1993; Bullough \& Draper, 2004; Geldens, 2007; Kagan, 1992; Williams et al., 1998). This places a great demand on the professionalism of mentor teachers in stimulating prospective teachers to learn from their practical experiences in the school setting. In practice, mentor teachers' supervisory styles are manifested in large part in the intentions, the approach and the contents of their dialogues with prospective teachers. In these respects, mentor teachers have a considerable influence on how and what prospective teachers learn (Feiman-Nemser, 2000; Geldens, 2007; Glickman \& Bey, 1990).

How mentor teachers behave during their mentoring dialogues is a question that has been studied from various perspectives and in differing contexts. This has led to a certain amount of confusion about the exact meaning of the terms used by researchers in describing mentor teachers' work and the mentoring dialogues they conduct (Sundli, 2007). In this literature study, therefore, we first of all survey the existing array of diverse terminology. No encompassing and coherent conceptual framework exists for studying mentor teachers' supervisory behaviour in mentoring dialogues. Such a framework could be helpful in research and development in the context of mentoring. Hence, the aim of this review study is to map key aspects of mentor teachers' supervisory behaviour in mentoring dialogues as a starting point for developing a conceptual framework.

\section{Terminology}

In the literature, a plethora of terms, explanations and expectations can be found with reference to the mentor's role, both within and outside the field of education (Mertz, 2004; Turner, 1993). In the field of teacher education, this confusion is rooted in three different sources: various social positions from which supervisory activities can be undertaken, changed role expectations of mentor teachers and diversity of terms used to refer to mentoring dialogues.

\subsection{Three social positions}

The first source for the confusion is the diversity in terminology to denote different social positions from which supervisory activities can be undertaken. A social position refers to the position of a person in relationship to others, in both large and small group settings (De Jager, Mok, \& Sipkema, 2004). This is what Merton (1968) calls "social 
status". In teacher education, three social positions can be distinguished from which supervisory activities can be undertaken. We speak of the "first position" when supervisory activities are carried out by a member of the school staff who is mostly working in the classroom as a teacher. In the literature, this position is diversely referred to as "mentor" (Edwards \& Collison, 1996; Edwards \& Protheroe, 2004; Evertson \& Smithey, 2001; Franke \& Dahlgren, 1996; Geldens, 2007; Hawkey, 1998a, 1998b; Martin, 1997; Orland-Barak \& Klein, 2005; Stanulis \& Russell, 2000; Veenman \& Denessen, 2001; Vonk, 1996; Wang, 2001; Wang, Strong, \& Odell, 2004; Williams et al., 1998), "mentor teacher" (Feiman-Nemser, Parker, \& Zeichner, 1992; Strong \& Baron, 2004), "school-based mentor" (Edwards, 1997; Hughes, 1998; Timperley, 2001), "school teacher mentor" (Haggarty, 1995; Turner, 1993), "class teacher" (Dunne \& Bennett, 1997; Edwards \& Protheroe, 2004), "cooperating teacher" (Borko \& Mayfield, 1995; Coulon, 1994; Dunn \& Taylor, 1993), "coach" (Engelen, 2002; Veenman \& Denessen, 2001), "coach-teacher" (Edwards \& Green, 1999), and "induction tutor" (Harrison, Lawson, \& Wortley, 2005). We speak of the "second position" when supervisory activities are carried out by someone who is part of the school staff or school district, and is not working as a teacher. Such a personnel is referred to as: "support teacher" (Feiman-Nemser, 2001; Feiman-Nemser et al., 1992), "teacher tutor or professional tutor" (Turner, 1993), "associate-tutor" (Collison \& Edwards, 1994) or "mentor" (Achinstein \& Barrett, 2004; Orland, 2001; Wang et al., 2004). The term "teacher educator", traditionally used for staff at teacher training institutes is currently also used for staff at the school district level who are involved in supervising prospective teachers (Feiman-Nemser et al., 1992; Orland, 2001). We speak of the "third position" when supervisory activities are carried out by a member of a teacher education institute or university. They are not employed by the school where the prospective teacher is working and are usually referred to as "supervisors" (Borko \& Mayfield, 1995; Byra, 1994; Dunne \& Bennett, 1997; Vásquez, 2004; Waite, 1992; Zeichner \& Listen, 1985) and "tutors" (Ben-Peretz \& Rumney, 1991; Collison \& Edwards, 1994; Haggarty, 1995; McNamara, 1995). In this study, we are concerned with supervisory activities undertaken from the first position. We refer to personnel in this position with the term "mentor teacher". This is a teacher of pupils with an additional responsibility as a mentor of prospective teachers. As a synonym for supervisory activities undertaken by the mentor teacher the term "mentoring" is used.

\subsection{Changed role expectations}

A second source for the confusion about terminology was the change of attitudes and expectations regarding the role of the mentor teacher which occurred during the 1990s. Similarly to De Jager et al. (2004), we have defined the term "role" as being the expected behaviour within a "social position". Within a social position, there are various roles that can be taken on. Roles and role expectations can change with the years. In the seventies and eighties, supervising teachers focused mainly on socialisation of prospective teachers within the school organisation by discussing day-to-day events, by giving advice, instruction and explanation. Field (1994, p. 46) describes this role as follows: “... welcomed the students into the school, made sure they knew the 'geography' of the building, introduced them to the staff, told them were to buy their lunch, ... etc." From introducing the prospective teacher to the way the school worked, mentoring gradually also came to include the encouragement of the new teacher to grow professionally through reflection on his or her own practice (Feiman-Nemser, 2001). This role shift requires also that mentor teachers attend to prospective teachers' present "concerns". Quite some confusion exists about the meaning of the word "reflection" (Rogers, 2001). Several authors wrote about the subject (Dewey, 1933; Hatton \& Smith, 1995; Luttenberg, 2002; Zeichner \& Listen, 1985). Korthagen (2001, p. 58) states that most conceptualisations of reflections can be brought together by the following definition: reflection is the mental process of trying to structure or restructure an experience, a problem, or existing knowledge or insight. The term Schön (1987) uses for the process of restructuring is "reframing". Several models describe how reflection in teacher learning should take place (e.g. Ferry \& Ross-Gordon, 1998; McAlphine, Weston, Beauchamp, Weiseman, \& Beauchamp, 1999). Systematic reflection does not come about by itself (Korthagen, 1988; Van Eekelen, 2005). It requires support in the form of supervisory activities (Kwakman, 2003).

Despite a high degree of consensus (Clinard \& Ariav, 1998; Feiman-Nemser, 2001; Field, 1994a, 1994b; Veenman $\&$ Denessen, 2001) about expected changes in the mentor teacher's role, a clear and manageable terminology did not evolve. At times, the term "mentor" is used as starting point for describing any changes in the role and at other times as end point: from "cooperating teacher" to "mentor" (Clinard \& Ariav, 1998), from "supervisor" to "mentor teacher" (Field, 1994b), from "mentor" to "coach" (McLennan, 1995; Veenman \& Denessen, 2001), from more conventional approaches that emphasize situational adjustment, technical advice and emotional support to "educative mentoring" 
(Feiman-Nemser, 2001). The terminological diversity is aggravated by the fact that some authors use the term "mentor" to indicate a social position (Jacques, 1992; Schein, 1978; Vonk, 1996; Zelditch, 1990), while others (Orland, 2001) use the same term to indicate a role.

\subsection{Dialogues: diversity of terms}

The third source for the diversity in terminology is the wide range of terms used to refer to the dialogues between mentor teachers and prospective teachers. Holland (1989) noted that in the period before 1990, the term "supervisory conference" had been used for thirty years to describe the dialogue between a mentor teacher and a prospective or experienced teacher. With the introduction of the concept of school-based teacher education in the beginning of the 1990s, many new terms were introduced, while in fact they all refer to the same type of mentoring dialogues. In the literature, the following terms are to be found: "post-lesson conferences" (Ben-Peretz \& Rumney, 1991; Coulon, 1994), "supervisors' talk" (Waite, 1992), "supervisory conference" (Byra, 1994; Waite, 1993), "post-teaching conferences" (Coulon, 1994), "mentoring sessions" (Franke \& Dahlgren, 1996), "post-agenda discussion" (Dunne \& Bennett, 1997), "coaching conversation" (Martin, 1997), "coaching conference" (Veenman \& Denessen, 2001), "post-observational discourse" (Hughes, 1998), "dialogue" (Williams et al., 1998), "mentor-protégé-conferences" (Evertson \& Smithey, 2001), "post-observation interviews" (Edwards \& Protheroe, 2004), "post-observation meetings" (Vásquez, 2004), "professional review meeting" (Harrison et al., 2005), "mentoring conversation" (Achinstein \& Barrett, 2004; Geldens, Popeijus, Peters, \& Bergen, 2005; Orland-Barak \& Klein, 2005; Strong \& Baron, 2004; Timperley, 2001).

In the framework of this study, we have chosen to use the term "dialogue" or "mentoring dialogue" to refer to the conversation between the mentor teacher and the prospective teacher, as it should be seen as a formal two-way conversation. Terms such as "conversation", "discourse", "talk" and "conference" are not so appropriate. The term "conversation" does not indicate the number of interlocutors, and the term "discourse" can be applied to a monologue or to a situation involving more than two interlocutors. The term "talk" indicates a more informal chat, whereas mentoring dialogues can have a more formal nature. The term "conference" tells us little about how many participants are present and gives little indication of the nature of what is said.

\section{Research questions}

The apparent diversity of research into mentor teachers' varying roles and supervisory behaviour highlights the lack of a single conceptual framework capable of describing how mentor teachers behave during dialogues. In order to build a conceptual framework suitable for studying mentor teachers' supervisory behaviour in dialogues with prospective teachers, key aspects of mentor teachers' behaviour should be identified. Hence, the research questions are:

1. Which key aspects of mentor teachers' supervisory behaviour in mentoring dialogues are investigated in previous research?

2. What is known from previous research on mentor teachers' supervisory behaviour in mentoring dialogues?

3. How can the extracted key aspects be connected to build a conceptual framework for studying mentor teachers' supervisory behaviour in mentoring dialogues?

\section{Method}

Because of the mainly qualitative nature of the research material and the limited number of empirical studies we did not conduct a quantitative meta-analysis. We used the approach of narrative literature study (Van IJzendoorn, 1998) and carried this out in three phases. In the first phase, five criteria were applied to the selection of the studies. Empirical studies (1) were selected and the studies had to be conducted from 1990 till 2006 (2). Studies were selected which focused on supervisory behaviour of mentor teachers in the workplace (3) through analysing mentoring dialogues (4) that were conducted in authentic, real-life situations (5). We chose the year 1990 as a starting point, because of the various developments in the field of teacher education, notably the increase in the importance of the workplace as a learning environment (Eraut, 2000) and an increase in the importance of the reflective paradigm within mentoring (Pajak, 1993). 
We retrieved publications which satisfied the above criteria from the Educational Resources Information Center (ERIC) catalogue and the following relevant journals: American Educational Research Journal, Australian Educational Research, British Educational Research Journal, British Journal of Teacher Education, Educational Research, Journal of Curriculum and Supervision, Journal of Counseling and Development, Journal of Educational Measurement, Journal of Educational Research, Journal of Teacher Education, Journal of Education for Teaching, Journal of Curriculum Studies, Teaching and Teacher Education and Teaching in Higher Education. To prevent any relevant studies from being overlooked, we used a wide range of search terms, not only for the mentor teacher, but also for the dialogues. These included combinations of key words such as "mentor teacher" and "dialogue". For phrases referring to the mentor teacher, we used the terms "mentor", "mentor teacher", "cooperating teacher", "supervisor", "tutor", "teacher educator", and "coach". For terms referring to the dialogues we used the words "dialogue", "discourse", "conversation", "talk" and "conference". All the key words have been indexed in both singular and plural forms. One author searched publications using the key words formulated in singular form, and one other author searched with keywords in the plural form. The title and abstract of each of the retrieved publications were printed. The final selection was stripped of double publications, whereupon 379 hits remained.

Then a second selection phase followed, in which the sources identified had to meet four criteria: supervisory activities undertaken from the "first position", by a teacher of pupils who have an additional responsibility as a mentor of prospective teachers (1), each dialogue took place between one mentor teacher and one prospective teacher and referred to actual (teaching) experiences of the prospective teacher (2), the relationship between mentor teacher and prospective teacher was not a peer-coaching relationship, but more or less hierarchical (3) and the analysis of dialogues occurred based on tape recordings, either audio or video, transcripts or observations (4). On the basis of printed titles and abstracts, the two authors independently selected studies which met the criteria. Subsequently, to realize consensus concerning the definite selection, the studies both authors selected separately, were exchanged and discussed. In those situations where the decision differed or where a decision could not be made, full text documents were obtained and were re-screened for inclusion on the basis of consensus between the two authors. Ultimately, 26 studies were selected which met all four criteria.

In the third phase, from the 26 selected studies data were extracted with reference to three basic features: the year and country where the study was carried out, relevant (parts of the) research question(s) or aim, and core elements of the research method(s) used. The most important part of the third research phase was to map key aspects of mentoring dialogues studied in previous empirical research (question 1), to describe mentor teachers' behaviour in mentoring dialogues concerning these aspects (question 2) and to try to connect the selected aspects in a coherent conceptual framework (question 3). To achieve this, the two authors independently made a summary of each study, containing the basic features of the study. They also separately listed aspects of mentoring dialogues which were investigated in the selected studies.

To answer the first research question, both authors exchanged the key aspects they listed and discussed them to realise consensus. To be able to answer the second research question, both authors independently categorised the findings of the studies using the extracted key aspects. The categorisations were exchanged and discrepancies were discussed and resolved. Extracted descriptive characteristics of the studies in the review were summarised in Appendix A. To answer the third research question, the key aspects of mentoring dialogues extracted from the selected empirical studies were discussed to establish if they could contribute to the development of a conceptual framework. An important criterion was the degree to which in the selected studies empirical evidence indicated that a specific aspect connects distinctive mentor teachers' behaviour in mentoring dialogues. Decisions were made on the basis of consensus between two authors. At the end of the process all five authors discussed in which way the selected key aspects of mentoring dialogues could be related to each other in a conceptual framework for studying mentor teachers' supervisory behaviour in mentoring dialogues. Also in this phase, decisions were made on the basis of consensus. Using these key aspects to form a conceptual framework requires a kind of creativity and intuition during the stage of data analysis and interpretation, as is emphasised by Van IJzendoorn (1998).

\section{Findings}

After a description of the three basic features of the selected studies, five key aspects of mentor teachers' behaviour in mentoring dialogues are outlined. A model is derived based on the inventory of key aspects, which can be helpful in mapping mentor teachers' behaviour in mentoring dialogues. 


\subsection{Features of the selected studies}

\subsubsection{Year of publication and country where the study was carried out}

A total number of 26 relevant sources were selected which met the inclusion criteria of phases 1 and 2 of the method: 20 articles from journals, 4 papers, 1 research report and 1 book. These sources covered research carried out between 1990 and 2006: 31\% between 1990 and 1995, 31\% between 1996 and 2000 and 38\% between 2001 and 2005. The authors of the selected studies come from the USA (35\%), UK (35\%) and other countries (31\%) including Israel, Sweden, New Zealand, Canada and The Netherlands.

\subsubsection{Research questions of the selected studies}

The research questions or aims of the selected studies mainly dealt with seven themes. If a study dealt with more than one theme, it is mentioned here only once. The themes are: "the content of the dialogues" (Borko \& Mayfield, 1995; Edwards \& Collison, 1996); "mentor teacher style/supervisory skills" (Ben-Peretz \& Rumney, 1991; Dunne \& Bennett, 1997; Feiman-Nemser \& Parker, 1990; Feiman-Nemser et al., 1992; Geldens et al., 2005; Haggarty, 1995; Hawkey, 1998b; Martin, 1997; Stanulis, 1995; Williams et al., 1998); "specific supervisory skills: giving advice" (Dunn \& Taylor, 1993; Strong \& Baron, 2004); "conceptions of mentoring" (Edwards \& Protheroe, 2004; Franke \& Dahlgren, 1996; Orland-Barak \& Klein, 2005); "effects of training on mentor teachers" (Crasborn, Hennissen, \& Brouwer, 2005; Evertson \& Smithey, 2001; Timperley, 2001; Veenman \& Denessen, 2001); "effects of supervisory activities by the mentor teachers on prospective teachers" (Coulon, 1994; Harrison et al., 2005; Hawkey, 1998a; Hughes, 1998); "influence of cultural context on mentor teachers behaviour" (Wang et al., 2004).

\subsubsection{Characteristics of the research methods}

The selected studies display a wide variety in the number of respondents. The number of mentor teachers per study averaged 10, ranging from 1 to 57 . The number of prospective teachers averaged 11, ranging from 1 to 57 . The average number of dialogues analysed is 24 , ranging from 4 to 114 . Quite a few researchers used an established analysis framework. This was the case in 10 of the studies. In 10 other studies, a new framework or new categories were developed on the basis of the raw data according to the idea of "grounded-theory" (Edwards \& Protheroe, 2004; Hawkey, 1998a, 1998b; Martin, 1997; Orland-Barak \& Klein, 2005; Stanulis, 1995). In two studies, researchers combined using an existing analysis framework and developing a new one. In four studies, there was merely a description of the results with no application of a framework. The recording of the dialogues was mainly done by audiocassettes from which a transcription was made. In one study (Ben-Peretz \& Rumney, 1991), dialogues were not taped, but direct observations were used. The unit of analysis differed between the studies: in $27 \%$ of the studies whole dialogues were used as the unit of analysis, $62 \%$ used (a) part(s) of the dialogue. Parts of dialogues were referred to with quite diverse terminology, for instance: "instances of talk, i.e. a unit of talk, uttered by one person, which focused on a single idea" (Dunne \& Bennett, 1997, p. 231), "guided-teaching episode" (Borko \& Mayfield, 1995, p. 504), "a meaning unit, defined as a string of words which carry one meaning in the context of the conversation" (Edwards \& Protheroe, 2004, p. 188), or "a theme, defined as a discussion or monologue about a particular idea or event" (Haggarty, 1995, p. 189). Likert scales were used for measuring the effects of training by Evertson and Smithey (2001), Veenman and Denessen (2001), and Timperley (2001) to score different behaviours of mentor teachers during dialogues. To analyse the data, three researchers used computer programmes such as Qualitative Solutions Research (Harrison et al., 2005; Hughes, 1998) or Kwalitan (Geldens et al., 2005).

\subsection{Five aspects of mentoring dialogues}

The aspects of mentoring dialogues on which the selected studies focussed differ from study to study. One or more of the following five aspects were considered: content and topics dealt with, the style and supervisory skills of the mentor teacher, the mentor teachers' input, time aspects of the dialogue and phases of the dialogue.

\subsubsection{Content and topics}

The content of the dialogues was a concern in 14 studies. The topics in mentoring dialogues identified fall mostly into three main categories: "instruction and organisation" (planning, approach, material, maintaining order, and classroom management), "the pupils and the class" (behaviour, learning styles, aptitude, reactions, learning process) and "the 
subject matter" (sources, terms, ideas). In addition, a category of "miscellaneous" can be distinguished including topics such as prospective teachers' professional development and requirements from the training institute.

During mentoring dialogues, the mentor teachers are mainly concerned with the instructional and organisational competence of the prospective teacher (Ben-Peretz \& Rumney, 1991; Dunne \& Bennett, 1997; Edwards \& Collison, 1996; Edwards \& Protheroe, 2004; Feiman-Nemser \& Parker, 1990; Hawkey, 1998b; Hughes, 1998). This is also reflected in the studies of specific -supervisory skills such as "giving advice" to the prospective teacher or "giving assignments". Strong and Baron (2004) record that $88 \%$ of the advice given to prospective teachers concerns the instructional aspects and classroom management. Coulon (1994) reports that most of mentor teachers' comments concern prospective teachers' instruction lesson content, management, organisation and feedback. Very few mentor teachers' comments dealt with the pupils, the class and the actual lesson content. In a few studies instructional and organisational aspects are not the most important ones. In a comparative study of American and Chinese mentors, Wang et al. (2004) showed that the latter were much more concerned about lesson content than their American counterparts. Feiman-Nemser and Parker (1990) used case studies to show that it is almost impossible not to refer to the subject matter during mentoring dialogues.

\subsubsection{Style and supervisory skills}

Another aspect of the mentoring dialogues is mentor teachers' "style and supervisory skills". Specific supervisory skills are seen as indicators of a particular style of mentoring. In a number of studies, style and supervisory skills are dealt with separately, while others deal with them simultaneously. In seven studies, an explicit analysis framework was used to categorise the various styles identified. Well-known is the distinction between a directive and a non-directive style. Using the directive style a mentor teacher tells the prospective teacher what to do, assesses, corrects, recites and informs. This is evidenced by terminology such as "authoritarian" (Ben-Peretz \& Rumney, 1991), "directive and informing" (Hawkey, 1998a; Williams et al., 1998), "critical" (Evertson \& Smithey, 2001), "instructive" (Harrison et al., 2005), "corrective" (Franke \& Dahlgren, 1996), advising (Crasborn et al., 2005). Then, there are less directive styles, often described with terms such as "reflective" (Franke \& Dahlgren, 1996; Harrison et al., 2005), "cooperative" (Ben-Peretz \& Rumney, 1991), "guiding" (Evertson \& Smithey, 2001; Harrison et al., 2005), "elicitive" (Hawkey, 1998a; Williams et al., 1998).

Most untrained mentor teachers appear to prefer the directive style (Ben-Peretz \& Rumney, 1991; Crasborn et al., 2005; Evertson \& Smithey, 2001; Franke \& Dahlgren, 1996; Harrison et al., 2005; Williams et al., 1998). BenPeretz and Rumney (1991) note that $74 \%$ of dialogues are more authoritarian and prescriptive than cooperative in nature. The prescriptive style can be characterised as instructive, critical, with few questions and accompanied by a personal expression of support. Williams et al. (1998) and Franke and Dahlgren (1996) have reported similar findings, according to which the prospective teacher views the mentor teacher as a role model, often emulating the mentor teachers' way of doing things. Mentor teachers consider it important to transmit their own subject matter knowledge to the prospective teacher (Ben-Peretz \& Rumney, 1991). Also mentor teachers use their own knowledge and experience as a teacher as a frame of reference for the dialogue (Haggarty, 1995). Not all researchers found that the directive style is dominant in the dialogues. Some mentor teachers do allow prospective teacher opportunities to reflect on their own performance. Hawkey (1998a) reports on one mentor teacher who, although using a directive style, was able to encourage the prospective teacher to reflect critically on his own performance and to learn from this. Another exception to the directive style is reported by Harrison et al. (2005). They concluded that trained mentor teachers are able to use a more guiding and reflective style in their dialogues.

A reason emerging from the studies for the more directive styles of mentor teachers is that they are more concerned with the learning process of their own pupils than that of the prospective teacher under their supervision (Edwards \& Collison, 1996; Edwards \& Protheroe, 2004). Given the nature of teaching and the need to progress in the curriculum, mentor teachers may want to focus on the instructional aspects of the teaching performed by the prospective teacher rather than their learning processes (Geldens et al., 2005). This means for example that the emphasis is not on the prospective teacher's concerns and learning objectives. In a study by Orland-Barak and Klein (2005), it appears that the instrumental and the developmental narrative of mentoring were both present in mentor teachers' approaches. They maintain that the approach chosen can also have a political element. On the one hand, the mentor teacher is operating within the parameters laid down by government focusing on pupil's achievement and instructional aspects of teaching (instrumental narrative). On the other hand, the mentor teacher is operating within the parameters laid down by the teacher education institute, which is more concerned with the prospective teacher's own learning (development 
narrative). It also appears that during mentoring dialogues, mentor teachers can be formal and unresponsive, particularly with regard to ideas put forward by prospective teachers. These ideas are then seldom taken up by the mentor teacher, nor investigated further. The prospective teacher is seldom challenged and the emphasis is more on "comfort" rather than on "competence" (Dunne \& Bennett, 1997; Edwards \& Collison, 1996).

In 16 of the selected studies, specific supervisory skills of mentor teachers were examined (Crasborn et al., 2005; Dunn \& Taylor, 1993; Edwards \& Protheroe, 2004; Evertson \& Smithey, 2001; Feiman-Nemser et al., 1992; Geldens et al., 2005; Haggarty, 1995; Harrison et al., 2005; Hawkey, 1998b; Hughes, 1998; Orland-Barak \& Klein, 2005; Strong \& Baron, 2004; Timperley, 2001; Veenman \& Denessen, 2001; Wang et al., 2004; Williams et al., 1998). Characteristics of mentor teachers' directive supervisory skills were: assessing, appraising, instructing, confirming, expressing one's own opinion, offering strategies and giving feedback. The non-directive supervisory skills include the following: asking questions, guiding to developing alternatives, reacting empathetically, summarising and listening actively.

According to Edwards and Protheroe (2004), Hawkey (1998b), Williams et al. (1998), directive supervisory skills are dominant in most mentoring dialogues and non-directive supervisory skills are less frequent. Evertson and Smithey (2001) state that this is particularly the case with untrained mentor teachers. These mentor teachers give criticism, do not encourage further analysis of the situation, do not ask questions and are quick to give tips and advice. Geldens et al. (2005) talk about a strong emphasis on giving feedback with little focus on challenging the prospective teacher, giving explanations or coming to some sort of agreement with the prospective teacher about how to proceed further. This is confirmed in a study by Hughes (1998) showing that less than $1 \%$ of the prospective teachers were asked to explain their performance. Wang et al. (2004) observed that Chinese mentor teachers gave compliments, suggestions and advice and were critical. A supervisory skill occurring frequently in mentoring dialogues is advising. Hughes (1998) concludes that mentor teachers give indirect advice by stating what they have seen in the lesson, telling what they considered in appropriate and by explaining what they would have done in a situation. By doing so they imply that their own practice is the acceptable model. In Strong and Baron's study (2004) of dialogues, $20 \%$ of the dialogues was focussing on giving advice. Of the 206 suggestions made, $80 \%$ were indirect advice and the remainder was direct. Timperley (2001) found that much advice was given without asking the prospective teacher if he or she found this advice useful in solving any problems he or she was experiencing. Dunn and Taylor (1993) found that mentor teachers gave advice about specific instances without extrapolating to other situations.

Within the trends described above, there is a difference between mentor teachers in their ability to be specific during dialogues and to probe certain topics more deeply (Borko \& Mayfield, 1995). This applies also to the degree of directiveness or directionality (Glickman, 1981). Not all mentor teachers are mainly directive in their approach. A small number of mentor teachers manages to create an environment in which prospective teachers are encouraged to raise more general questions and to discuss their own concerns. Mentor teachers do this by listening actively and by giving a clear summary of situations from the point of view of the prospective teacher (Edwards \& Collison, 1996).

To summarise, different styles and approaches as well as the various supervisory skills can be placed on a dimension of directiveness, with the non-directive style at one end and the directive style at the other. It can be concluded that the style and the supervisory skills of untrained mentor teachers mostly fall into the directive rather than the non-directive category. Several researchers conclude that the use of supervisory skills can be influenced by training (Crasborn et al., 2005; Evertson \& Smithey, 2001; Harrison et al., 2005; Timperley, 2001; Veenman \& Denessen, 2001) or by a form of coaching (Hawkey, 1998b).

\subsubsection{Mentor teachers' input}

In five studies (Feiman-Nemser et al., 1992; Geldens et al., 2005; Haggarty, 1995; Hughes, 1998; Wang et al., 2004), the researchers examined who took the most initiative during dialogues, the mentor or the prospective teacher, and what levels of participation, both displayed. All these studies show that it is the mentor teacher who usually introduces the topics into dialogues and thus is the source of active input. If the mentor teacher reacts to the input of the prospective teacher, then the input is of a reactive nature. Generally, the mentor teacher also directs the dialogue (Feiman-Nemser et al., 1992; Geldens et al., 2005; Haggarty, 1995), asks the questions and makes suggestions. Hughes (1998) found that in $69 \%$ of the units coded mentors teachers dominated the dialogue. Wang et al. (2004) found that Chinese mentor teachers initiated $80 \%$ of the topics. Geldens et al. (2005) comment that a less active mentor teacher and a prospective teacher who takes more initiative, will not automatically lead to more effective supervision. Overall, it can be concluded that mentor teachers give more active than reactive input during mentoring dialogues. 


\subsubsection{Time aspects}

In 11 of the studies, elements of time were investigated. Ten researchers (Ben-Peretz \& Rumney, 1991; Borko \& Mayfield, 1995; Crasborn et al., 2005; Dunne \& Bennett, 1997; Edwards \& Collison, 1996; Geldens et al., 2005; Haggarty, 1995; Hawkey, 1998b; Hughes, 1998; Strong \& Baron, 2004; Wang et al., 2004) mentioned the duration of the mentoring dialogues. Four researchers (also) reported mentor teachers' speaking time during dialogues (Crasborn et al., 2005; Dunne \& Bennett, 1997; Hawkey, 1998a; Hughes, 1998).

The duration of dialogues between mentor teachers and prospective teachers varied from $5 \mathrm{~min}$ (Borko \& Mayfield, 1995; Edwards \& Collison, 1996) to 60 min (Hawkey, 1998b; Strong \& Baron, 2004). Dunne and Bennett (1997) found that the mentor teacher contributed the greater part of verbal interaction in the dialogue. In the study by Hughes (1998) the mean percentage of total mentor talk was 69\%. Crasborn et al. (2005) found that after training in supervisory skills, mentor teachers' total speaking time during mentoring dialogues on average decreased with $19 \%$. Researchers do not agree on any link between the duration of the dialogues and the amount of time the mentor teacher is active in the dialogues on the one hand, and the implementation of specific speaking skills and the quality of the dialogues on the other. According to Hughes (1998), reflection by the prospective teacher can only take place during a longer dialogue, while Geldens et al. (2005) maintain that the duration of the dialogue has little effect on the degree of initiative or reflection on the part of prospective teachers. Borko and Mayfield (1995) report that the longer the duration of the dialogue, the more specific suggestions were made by the mentor teacher. Hawkey (1998a) established that the mentor teacher who has a more directive style is a more active interlocutor and talks the most in the dialogue, whereas the mentor teacher who has a more cooperative style is active for half of the dialogue. Crasborn et al. (2005) note that using directive skills takes up more time than using non-directive skills.

\subsubsection{Phases}

The aspect "phases of the dialogue" was examined in six of the selected sources. In three of the studies (Evertson \& Smithey, 2001; Geldens et al., 2005; Harrison et al., 2005), an analysis framework was used, while in three other studies, this was not the case (Ben-Peretz \& Rumney, 1991; Feiman-Nemser et al., 1992; Wang et al., 2004). Geldens et al. (2005) conclude that in the dialogues generally issues arising from situations occurring in the lessons discussed are addressed and that mentor teachers make little reference to previous dialogues and few decisions about expectations for any future lessons. Evertson and Smithey (2001) established that untrained mentor teachers did not refer to previous dialogues and gave a range of suggestions, while trained mentor teachers were able to make observations and to assist prospective teachers in reconstructing lessons. Harrison et al. (2005) show that trained mentor teachers were better able to guide prospective teachers to analyse their teaching performance by clarifying their actions ("deconstructing practice") and allowed them to think of new ways of dealing with situations ("constructing practice").

Although researchers were not always explicitly examining the phases of dialogues as a separate issue, many still reported findings concerning phases in the dialogue. Feiman-Nemser et al. (1992) note that mentor teachers began by giving a compliment and continued by taking the prospective teacher through the lesson, making comments and asking questions about each part of the lesson. Ben-Peretz and Rumney (1991) distinguish three phases in dialogues: opening with a general question, one-directional feedback and a conclusion with clear directions for future lessons. Chinese mentors began their dialogues with a compliment, followed this up with some critical comments and completed the dialogues by giving suggestions (Wang et al., 2004). With regard to the phases of mentoring dialogues, there appears to be a division between mentoring styles looking back on what happened in lessons and those looking forward to how to change future lessons.

\subsection{The MERID model}

From the apparent diversity of research into mentoring dialogues it is clear that so far there is no single conceptual framework available to study mentor teachers' supervisory behaviour during dialogues with prospective teachers. For the selection of key aspects which can contribute to the construction of such a framework a criterion was used, namely the degree to which in the selected studies empirical evidence indicated that a specific aspect connects with distinctive mentor teachers' behaviour in mentoring dialogues. In the selected studies no empirical data were reported indicating that the key aspects "content" and "phases" connect with distinctive mentor teachers' behaviour. Three out of five key aspects remained: "style/supervisory skills", "input", and to some degree the aspect "time". These key aspects are plausible candidates for constituting the MEntor (teacher) Roles In Dialogues (MERID) model (Fig. 1). The MERID model includes two dimensions. The horizontal axis represents the amount of directiveness displayed by the mentor 


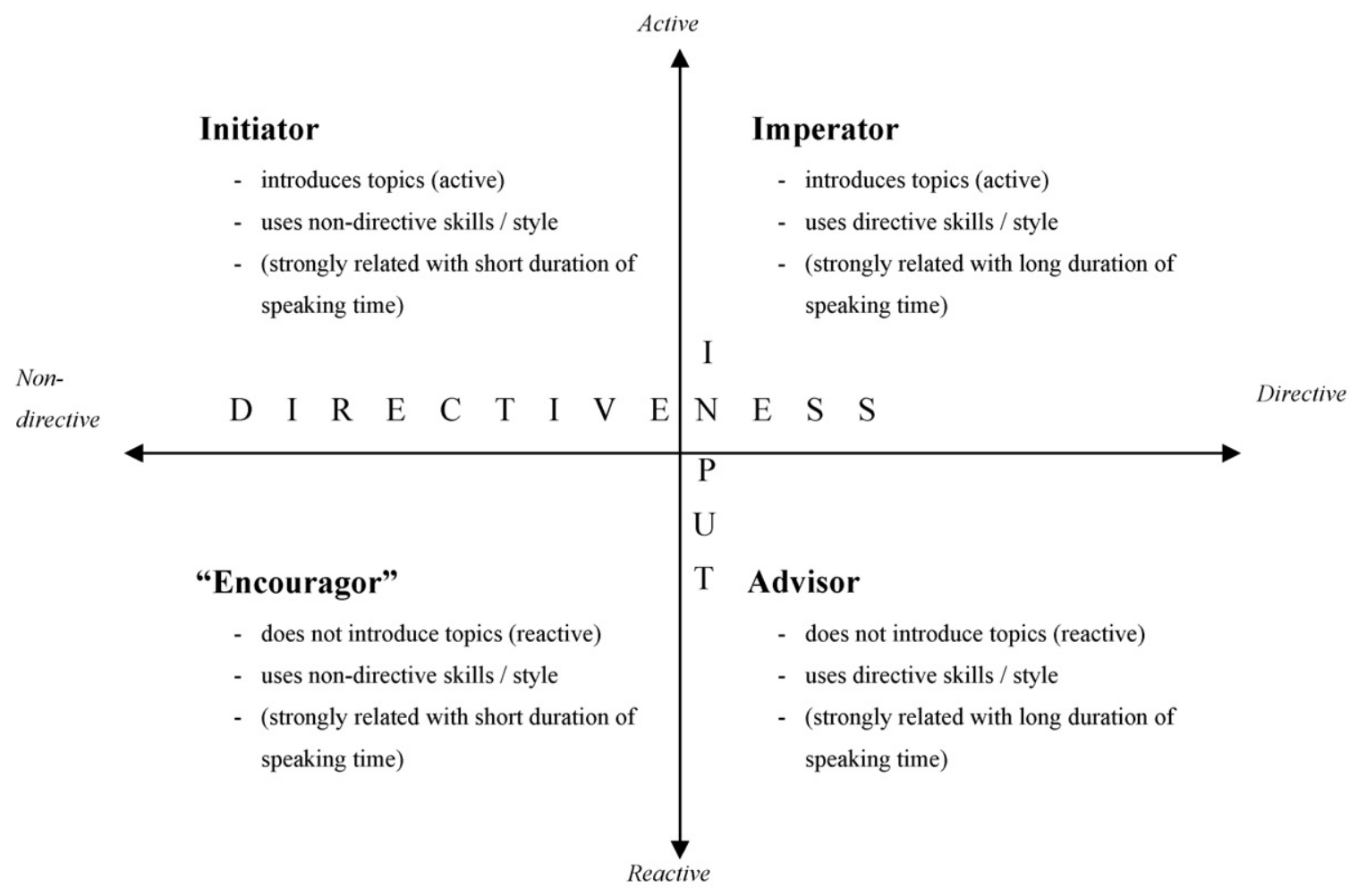

Fig. 1. The MERID model.

teacher. The vertical axis represents the degree of input by the mentor teacher. The combination of these two dimensions results in four different mentor teacher roles in mentoring dialogues: initiator, imperator, advisor and "encouragor". First the construction of the dimensions of the model is explained and secondly the mentor teachers' roles which emerge when these dimensions are combined, are described.

\subsubsection{Dimensions}

In 22 of the 26 selected studies, the key aspect "style/supervisory skills" was taken as an indicator of how a mentor teacher acts during dialogues. This indicator assesses the degree to which the mentor teacher steers the course of the dialogue. In the MERID model, this key aspect has been incorporated into the horizontal dimension of directiveness. This dimension is a continuum with two poles: directive and non-directive. On the basis of the literature studied, most mentor teachers can be placed on the right side of the horizontal axis, the mentor teacher instructing the prospective teacher and talking from the standpoint of his or her own experience and evaluating the behaviour of the prospective teacher (Ben-Peretz \& Rumney, 1991; Edwards \& Protheroe, 2004; Evertson \& Smithey, 2001; Franke \& Dahlgren, 1996; Harrison et al., 2005; Hawkey, 1998b; Williams et al., 1998). This behaviour can apparently be changed to some extend through training in supervisory skills (Crasborn et al., 2005; Evertson \& Smithey, 2001; Harrison et al., 2005; Timperley, 2001; Veenman \& Denessen, 2001) and by means of supervising mentor teachers (Hawkey, 1998b). The sources analysed suggest that the duration of the mentor teachers' speaking time can help distinguish between roles taken by mentor teachers. The data from four of the studies indicate that there is a relation between the duration aspect and the dimension of directiveness. Hawkey (1998a) showed that a mentor teacher whose style can be described as directive used more speaking time than a mentor teacher who used more elicitation during dialogues. Crasborn et al. (2005) showed that supervisory skills such as "giving advice" and "giving information", require more time than non-directive supervisory skills such as "asking questions" and "summarising content". Consequently, there may be a correlation between the duration of dialogues and the degree of directiveness. A mentor teacher who is directive in style may use more speaking time than a more non-directive mentor teacher. In the quadrants of the MERID model, this possible relationship is indicated by the formulations "strongly correlated with long duration of speaking time" and "strongly correlated with short duration of speaking time." 
Another key aspect connected to empirical evidence indicating mentor teachers' distinctive behaviour in dialogues is the degree of input made by the mentor teacher. In the MERID model, this key aspect has been incorporated into the vertical dimension of input. This dimension is a continuum with two poles: active and reactive. One of the findings from this review is that mentor teachers often give active input and are the ones who introduce the topics into the dialogues (Feiman-Nemser et al., 1992; Geldens et al., 2005; Haggarty, 1995; Wang et al., 2004). These mentor teachers can be placed in the upper half of the MERID model. There are also mentor teachers who can be placed in the lower half of the model, because they are more reactive to the prospective teachers' concerns (Edwards \& Collison, 1996). According to Feiman-Nemser (2001), a mentor teacher can encourage prospective teachers to reflect on their own experience if he or she is able to understand his or her concerns. An important indicator then, of the role of the mentor teacher in a dialogue is the question who introduces the topics.

The two dimensions of the MERID model are independent of each other. This can be illustrated with an example in which the mentor teachers' input is "active", visualised in the upper half of the MERID model, and an example in which his input is "reactive", visualised in the lower half of the MERID model. If the mentor teacher introduces actively a topic about for example an unruly pupil in the class, then he can choose to do this in a directive manner ("I think the pupil was unruly because of the previous lesson") or in a non-directive manner ("Can you tell me about the unruly pupil?"). If the mentor teacher reacts on the input of the prospective teacher, then he also can choose to do this in a directive way ("I would tell the pupil to...") or in a non-directive way ("What do you mean by unruly?").

\subsubsection{Four roles}

The four quadrants in the MERID model will now be illustrated with examples of transcriptions of recorded authentic dialogues between untrained mentor teachers (MT) and prospective teachers (PT) (Crasborn et al., 2005). Pupil names are fictitious. The role in the upper right quadrant is referred to as "imperator". The mentor teacher introduces a topic and uses directive interventions. An example of the imperator role is presented below. The mentor teacher introduces the topic of "reading comprehension" and subsequently uses directive interventions.

MT: In the reading comprehension lesson I thought you had a good diagram on the blackboard. The children thought the word web was very good.

PT: Yes.

MT: I saw that Frank and Paul had written on a piece of paper. The agreement is that they must use their notebook. You should tell them to do so.

PT: Oh yes, yes. I wanted them to write it in their notebook.

In the reviewed literature several authors present findings referring to the imperator role. Wang et al. (2004) emphasise that the Chinese teachers' approach consisted of a compliment, critical comments and suggestions for future lessons. Evertson and Smithey (2001) noted that untrained mentor teachers did not always refer back to the lesson, but immediately began giving various suggestions. Feiman-Nemser et al. (1992) found that after giving a compliment, the mentor teacher went through the lesson and gave comments on each part. Hughes (1998) states that mentor teachers first talked about what they had seen in the lesson, then indicated what they felt was not appropriate and then finally informed the prospective teacher what they would have done in that situation.

The role in the upper left quadrant is referred to as "initiator". The mentor teacher introduces a topic and then encourages the prospective teacher to think further about the topic. An example of the initiator role is presented below. The mentor teacher introduces the topic of "introduction into the school" and subsequently uses non-directive interventions.

MT: Niels, you've been here now for several days. What is your first impression about the school?

PT: Well, I immediately felt welcome in the team. As soon as I introduced myself I felt at home. Also, considering it's an old building, it's very nice.

MT: So you feel at home as a member of the team.

PT: Yes.

MT: What do you like about the old building?

PT: Well, I think it's good that there is a common hall that you can use. 
Timperley (2001) presents findings referring to the initiator role. In her research it appears that after training mentor teachers are able to express and formulate their input in such a way that the prospective teacher is able to address to the mentor teachers' topic.

The role in the lower right quadrant is referred to as "advisor". The mentor teacher reacts to the prospective teacher's input and gives advice on what to do. An example of the advisor role is presented below. The mentor teacher reacts to the topic introduced by the prospective teacher of "involving pupils in the lessons", and subsequently uses directive interventions.

PT: I had a question. When I am sitting in a circle with the pupils, how can I ensure that all pupils are involved in the lesson? You always seem to have some lazy ones who just look around.

MT: Yes, but I really think that it depends on the topic. Everyone of course has different interests and some are more interested than others. Personally I think that it very much depends on you to make the topic interesting and attractive by how expressive you are and by your own body language. And you can do that and you know you can. Constantly warning pupils doesn't help and just saying "pay attention" will get you nowhere. But you can involve pupils by maintaining eye contact, or by making a gesture, such as a wink, and by walking up to them to correct them. Or ask them questions. Remember you want to involve them in the lesson so ask them questions that are relevant to them, but about the topic.

Dunn and Taylor (1993) present findings referring to the advisor role. In their research we can see that advisor type mentor teachers react to questions and comments originating from the prospective teacher. They conclude that prospective teachers are not greatly challenged to reflect on other situations.

The role in the lower left quadrant is referred to as "encouragor". The mentor teacher reacts to the input of the prospective teacher and induces him or her to reflect on his or her performance in the classroom. An example of the "encouragor" role is presented below. The mentor teacher reacts to the topic introduced by the prospective teacher of "dealing with pupils" and subsequently uses non-directive interventions.

\section{MT: So Fred. How are things going?}

PT: Well, Theo is threatening to leave school. He is always saying things like "I want to leave school and I am going to talk to my mother about it." And then I am unsure of how to react. He is asking for attention and I have more children who need that too, and I can't give Theo all the attention he seems to need. If he can't do something he will say, "I can't do it. I know I'll get a 1 or an insufficient." And then if I ignore him he just carries on about leaving school and talking to his mother about it. I really don't know how to react. I have in the past just cut him off and not listened to him, and pretended I didn't hear what he said, but he just goes on and on. What should I say to him? I find it difficult.

MT: Do I understand you correctly that on the one hand you find it difficult to ignore him, but on the other hand you don't want him to talk to you in this way?

PT: That's right. I don't like it when he says these things, but it is a sign and he doesn't say it for nothing.

MT: Yes, yes. Can you think when this sort of behaviour first began?

In the reviewed literature several authors present findings referring to "encouragor" role. It appears that there are mentor teachers who can conduct a dialogue based on the concerns of the prospective teacher. The mentor teacher creates an environment which fosters reflection on the part of the prospective teacher and enables him or her to reflect on his or her behaviour both in and outside the classroom (Edwards \& Collison, 1996) and to think about broader pedagogical topics with regard to his or her pupils (Harrison et al., 2005).

\section{Conclusions and discussion}

In this literature study, we first of all create conceptual order to the various terms used in the context of mentoring in teacher education. In teacher education, three social positions can be identified from which supervisory activities can be undertaken. With these positions in mind it was possible to define and characterise our subject group as "mentor teachers", which are teachers of pupils with an additional responsibility as mentors of prospective teachers. We refer to 
this (social) position from which supervisory activities can be undertaken as the "first position". To express the formal two-way character of the conversations between one mentor teacher and one prospective teacher the term "mentoring dialogue" was chosen.

The aim of this review study was to map key aspects of mentor teachers' supervisory behaviour in mentoring dialogues as a starting point for developing a conceptual framework to use in research and development in the context of mentoring. As an answer to the first research question, from the selected empirical studies five key aspects of mentoring dialogues emerged, which are often the focus of research: content of the dialogue, mentor teachers' style and supervisory skills, mentor teachers' input, time aspects of the dialogue and phases in the dialogue. In answer to the second research question the selected studies report several findings concerning the studied aspects of mentoring dialogues. The topics discussed during the dialogues are mainly about instructional and organisational aspects and to a lesser degree about individual pupils, the class or the subject matter. The mentor teachers' style and supervisory skills could be described as mainly directive. Mentor teachers are the ones who usually decide upon the topics ("active input"). As far as speaking time was concerned, it are mainly the mentor teachers who do most of the talking. In most mentoring dialogues, there is generally a division between a phase of referring back to the lesson ("deconstruction") and a phase of looking ahead ("construction"). In answer to the third research question empirical evidence in the selected studies indicates that three key aspects connect with distinctive mentor teachers' behaviour in mentoring dialogues: style/supervisory skills, input and time aspects. These three aspects are plausible candidates to constitute a conceptual framework. We connected these key aspects in the MERID model, which shows four mentor teacher roles during mentoring dialogues: imperator, initiator, advisor and "encouragor".

We do not give a judgment on the best mentor teachers' role and agree with Williams et al. (1998) who state that a mentor teacher whose supervisory approach matches with the prospective teachers' needs is more effective. Moreover, prospective teachers report different preferences concerning the supervisory approach (Copeland, 1982; Glickman, 1985). Hence, we argue that prospective teachers' learning improves if mentor teachers are better at adapting to individual differences between prospective teachers and to different workplace situations in which several workplace features interact differently with specific characteristics of individual prospective teachers. Empirical evidence confirms the influence of personal and contextual (workplace) factors on (prospective) teachers' learning processes. Prospective teachers have different learning styles, which partially depend on their orientations towards learning (Korthagen, 1988; Oosterheert \& Vermunt, 2001). Prospective teachers' professional development takes place at different speeds, and thus, their needs and concerns change over time (Furlong \& Maynard, 1995). The quality of learning outcomes is also determined by the workplace (Eraut, 2007; Eraut, Alderton, Cole, \& Senker, 1998). Holton and Baldwin (2000) identified several features of the workplace influencing transfer of knowledge and skills. In the context of teacher education Geldens (2007) identified four characteristics of a "powerful" learning environment on the workplace: competences, continuity, cooperation agreements, and mentoring and coaching. All the above mentioned factors create a diversity of supervisory contexts and situations, which the mentor teacher has to anticipate on by developing a versatile repertoire of supervisory skills. This viewpoint is rooted in a situated constructivist perspective on (teachers') learning (Bereiter \& Scardamalia, 1993; Eraut, 2000; Lave \& Wenger, 1991; Schön, 1983). How a person learns a particular set of knowledge and skills is strongly intertwined with the situation in which this person learns.

In the last 15 years, a lot is published about mentoring and the required change in mentor teachers' behaviour and roles in dialogues. This study shows that in practice a change in mentor teachers' supervisory behaviour hardly takes place. Mentor teachers tend to work mostly from the imperator role. To be flexible in their approach mentor teachers should be able to take several roles in dialogues as distinguished in the MERID model. To put these roles into practice mentor teachers need a versatile supervisory repertoire. This requires training of mentor teachers (Gallego, 2001; Geldens, 2007; Giebelhaus \& Bowman, 2002; Odell et al., 2000). Effects of such trainings are reported to varying degrees (Edwards \& Green, 1999; Evertson \& Smithey, 2001; Harrison et al., 2005; Strong \& Baron, 2004; Timperley, 2001; Veenman \& Denessen, 2001). However, the available empirical evidence is still limited and too diverse to allow drawing definite conclusions about the influence of mentor teacher training on the use of supervisory skills.

The MERID model can provide conceptual coherence in studying mentor teachers' supervisory behaviour. It may contribute to a more conscious use and a better identification of mentor teachers' roles in dialogues. In this way the model may support further reflection on mentoring as well as the development of fruitful approaches for supporting mentor teachers in their work. After all, the mentor teachers seem to play a crucial role in the professional development of our future teachers. 


\section{Appendix A. Descriptive characteristics of studies in the review}

\begin{tabular}{|c|c|c|c|c|c|c|c|c|c|c|c|c|c|c|}
\hline \multirow[t]{2}{*}{ Studies/countries } & \multirow[t]{2}{*}{ Research questions ${ }^{\mathrm{a}}$} & \multicolumn{7}{|c|}{ Characteristics of the research methods } & \multicolumn{6}{|c|}{ Aspects of mentoring dialogues } \\
\hline & & $\begin{array}{l}\text { Number of } \\
\text { mentor } \\
\text { teachers } \\
\text { (MT) }\end{array}$ & $\begin{array}{l}\text { Number of } \\
\text { prospective } \\
\text { teachers } \\
\text { (PT) }\end{array}$ & $\begin{array}{l}\text { Number of } \\
\text { analysed } \\
\text { dialogues }\end{array}$ & $\begin{array}{l}\text { Analysis } \\
\text { framework } \\
\text { [exist- } \\
\text { ing/new/not } \\
\text { reported] }\end{array}$ & $\begin{array}{l}\text { Taped [yes } \\
\text { (audio/video)/ } \\
\text { no/not } \\
\text { reported] }\end{array}$ & $\begin{array}{l}\text { Transcription } \\
\text { [yes/no/not } \\
\text { reported] }\end{array}$ & $\begin{array}{l}\text { 'Unit of } \\
\text { analysis': } \\
\text { dialogue [as a } \\
\text { whole/part(s)] }\end{array}$ & $\begin{array}{l}\text { Content } \\
\text { [number of } \\
\text { categories] }\end{array}$ & $\begin{array}{l}\text { Style or skills } \\
\text { [style (number of } \\
\text { categories)/skills } \\
\text { (number of } \\
\text { categories)] }\end{array}$ & $\begin{array}{l}\text { Input [(a) amount } \\
\text { of input MT; (b) } \\
\text { type: initiation or } \\
\text { participation] }\end{array}$ & $\begin{array}{l}\text { Time [(a) } \\
\text { duration of one } \\
\text { dialogue (min); } \\
\text { (b) amount of } \\
\text { speaking time } \\
\text { MT] }\end{array}$ & $\begin{array}{l}\text { Phases } \\
\text { [number of } \\
\text { phases] }\end{array}$ & $\begin{array}{l}\text { Other } \\
\text { aspects }\end{array}$ \\
\hline $\begin{array}{l}\text { Ben-Peretz and } \\
\text { Rumney (1991), } \\
\text { Israel }\end{array}$ & $\begin{array}{l}\text { Is the cooperating teacher } \\
\text { mainly supportive or } \\
\text { evaluative? Is the mode of } \\
\text { interaction mainly } \\
\text { authoritative or cooperative? }\end{array}$ & 35 & 31 & 31 & Not reported & No & $\begin{array}{l}\text { No, scored } \\
\text { from } \\
\text { observation } \\
\text { protocols }\end{array}$ & $\begin{array}{l}\text { As a whole } \\
\text { (Likert scale) }\end{array}$ & 10 & Style (2) & & (a) $10-20 \mathrm{~min}$ & 3 & \\
\hline $\begin{array}{l}\text { Borko and Mayfield } \\
\text { (1995), USA }\end{array}$ & $\begin{array}{l}\text { What are the characteristics } \\
\text { of guided teaching } \\
\text { conferences between student } \\
\text { teachers and cooperating } \\
\text { teachers? }\end{array}$ & 12 & 4 & 9 & Existing & Not reported & Yes & Part & 5 & & & (a) $5-30 \mathrm{~min}$ & & \\
\hline $\begin{array}{l}\text { Crasborn et al. } \\
\text { (2005), NL }\end{array}$ & $\begin{array}{l}\text { Before and after training, } \\
\text { which interventions are used } \\
\text { by coaches with which } \\
\text { frequencies, for how much of } \\
\text { the time are coaches } \\
\text { speaking; how many } \\
\text { conversational turns are used? }\end{array}$ & 13 & 13 & 26 & New & Yes (video) & Yes & Part & & $\begin{array}{l}\text { Style (2) and } \\
\text { skills (15) }\end{array}$ & & $\begin{array}{l}\text { (a) Max. } 15 \mathrm{~min} \text {; } \\
\text { (b) decreased by } \\
19 \%\end{array}$ & & \\
\hline $\begin{array}{l}\text { Coulon (1994), } \\
\text { USA }\end{array}$ & $\begin{array}{l}\text { Identifying the influence of } \\
\text { cooperating teachers' } \\
\text { post-teaching conference task } \\
\text { statements on student } \\
\text { teachers' interactive } \\
\text { behaviours during subsequent } \\
\text { lessons (objective) }\end{array}$ & 2 & 2 & $\begin{array}{l}\text { Not } \\
\text { reported }\end{array}$ & Not reported & Yes (audio) & Yes & Part & 8 & & & & & $\begin{array}{l}\text { Realizing } \\
\text { task } \\
\text { statements }\end{array}$ \\
\hline $\begin{array}{l}\text { Dunn and Taylor } \\
\text { (1993), USA }\end{array}$ & $\begin{array}{l}\text { What is the nature of advice } \\
\text { that cooperating teachers give } \\
\text { to student teachers? Are there } \\
\text { differences between } \\
\text { experienced and novice } \\
\text { cooperating teachers? }\end{array}$ & 8 & 8 & 25 & New & Yes (audio) & Yes & Part & & Skills (9) & & & & \\
\hline $\begin{array}{l}\text { Dunne and Bennett } \\
\text { (1997), UK }\end{array}$ & $\begin{array}{l}\text { Ascertain the nature, content } \\
\text { and focus of the dialogues and } \\
\text { assess whether the different } \\
\text { role structure posited in the } \\
\text { mentoring model was evident } \\
\text { in practice (aim) }\end{array}$ & 4 & 4 & 8 & Existing & Yes (audio) & Yes & Part & 7 & & & $\begin{array}{l}\text { (a) } 10-20 \mathrm{~min} \text {; } \\
\text { (b) more than } \\
50 \%\end{array}$ & & \\
\hline $\begin{array}{l}\text { Edwards and } \\
\text { Collison (1996), } \\
\text { UK }\end{array}$ & $\begin{array}{l}\text { What is going on between } \\
\text { mentors and students in the } \\
\text { conversations before and after } \\
\text { teaching? }\end{array}$ & 11 & 21 & 21 & Existing & Yes & Not reported & Part & 6 & Style (1) & & (a) 5-20 min & & \\
\hline $\begin{array}{l}\text { Edwards and } \\
\text { Protheroe } \\
\text { (2004), UK }\end{array}$ & $\begin{array}{l}\text { What do mentors believe they } \\
\text { offer and what do student } \\
\text { teachers offer in } \\
\text { post-observation interviews? }\end{array}$ & 12 & 12 & 45 & New & Yes & Not reported & Part & 13 & Skills (13) & & & & \\
\hline $\begin{array}{l}\text { Evertson and } \\
\text { Smithey (2001), } \\
\text { USA }\end{array}$ & $\begin{array}{l}\text { Does a mentoring program } \\
\text { affect new teachers practice? }\end{array}$ & $\begin{array}{l}8 \text { exp. gr.; } \\
3 \text { contr. gr. }\end{array}$ & $\begin{array}{l}8 \text { exp. gr.; } \\
3 \text { contr. gr. }\end{array}$ & 11 & Existing & Yes (video) & $\begin{array}{l}\text { No, scored } \\
\text { from } \\
\text { videotape }\end{array}$ & $\begin{array}{l}\text { As a whole } \\
\text { (Likert scale) }\end{array}$ & & $\begin{array}{l}\text { Style (2) and } \\
\text { skills (4) }\end{array}$ & & & 2 & \\
\hline
\end{tabular}


Appendix A (Continued)

\begin{tabular}{|c|c|c|c|c|c|c|c|c|c|c|c|c|c|c|}
\hline \multirow[t]{2}{*}{ Studies/countries } & \multirow[t]{2}{*}{ Research questions $^{\mathrm{a}}$} & \multicolumn{7}{|c|}{ Characteristics of the research methods } & \multicolumn{6}{|c|}{ Aspects of mentoring dialogues } \\
\hline & & $\begin{array}{l}\text { Number of } \\
\text { mentor } \\
\text { teachers } \\
\text { (MT) }\end{array}$ & $\begin{array}{l}\text { Number of } \\
\text { prospective } \\
\text { teachers } \\
\text { (PT) }\end{array}$ & $\begin{array}{l}\text { Number of } \\
\text { analysed } \\
\text { dialogues }\end{array}$ & $\begin{array}{l}\text { Analysis } \\
\text { framework } \\
\text { [exist- } \\
\text { ing/new/not } \\
\text { reported] }\end{array}$ & $\begin{array}{l}\text { Taped [yes } \\
\text { (audio/video)/ } \\
\text { no/not } \\
\text { reported] }\end{array}$ & $\begin{array}{l}\text { Transcription } \\
\text { [yes/no/not } \\
\text { reported] }\end{array}$ & $\begin{array}{l}\text { 'Unit of } \\
\text { analysis': } \\
\text { dialogue [as a } \\
\text { whole/part(s)] }\end{array}$ & $\begin{array}{l}\text { Content } \\
\text { [number of } \\
\text { categories] }\end{array}$ & $\begin{array}{l}\text { Style or skills } \\
\text { [style (number of } \\
\text { categories)/skills } \\
\text { (number of } \\
\text { categories)] }\end{array}$ & $\begin{array}{l}\text { Input [(a) amount } \\
\text { of input MT; (b) } \\
\text { type: initiation or } \\
\text { participation] }\end{array}$ & $\begin{array}{l}\text { Time [(a) } \\
\text { duration of one } \\
\text { dialogue (min); } \\
\text { (b) amount of } \\
\text { speaking time } \\
\text { MT] }\end{array}$ & $\begin{array}{l}\text { Phases } \\
\text { [number of } \\
\text { phases] }\end{array}$ & $\begin{array}{l}\text { Other } \\
\text { aspects }\end{array}$ \\
\hline $\begin{array}{l}\text { Feiman-Nemser } \\
\text { and Parker } \\
\text { (1990), USA }\end{array}$ & $\begin{array}{l}\text { How might issues about the } \\
\text { teaching and learning of } \\
\text { academic content figure in } \\
\text { interactions between novices } \\
\text { and their mentors? }\end{array}$ & $\begin{array}{l}2 \text { (only } \\
\text { mentor } \\
\text { teachers) }\end{array}$ & 2 & $\begin{array}{l}\text { Not } \\
\text { reported }\end{array}$ & Not reported & Not reported & Not reported & $\begin{array}{l}\text { As a whole } \\
\text { (narrative) }\end{array}$ & 1 & & & & & \\
\hline $\begin{array}{l}\text { Feiman-Nemser et } \\
\text { al. (1992), USA }\end{array}$ & $\begin{array}{l}\text { Learning more about what } \\
\text { mentor teachers do when they } \\
\text { work with beginning teachers } \\
\text { (aim) }\end{array}$ & 3 & 3 & $\begin{array}{l}\text { Not } \\
\text { reported }\end{array}$ & Not reported & Not reported & Yes & $\begin{array}{l}\text { As a whole } \\
\text { (narrative) }\end{array}$ & 3 & $\begin{array}{l}\text { Skills (number } \\
\text { not reported) }\end{array}$ & (b) Participation & & 2 & \\
\hline $\begin{array}{l}\text { Franke and } \\
\text { Dahlgren (1996), } \\
\text { Sweden }\end{array}$ & $\begin{array}{l}\text { Discovering and describing } \\
\text { the meaning of mentors' } \\
\text { conceptions of mentoring } \\
\text { given in teaching practice } \\
\text { (aim) }\end{array}$ & 10 & 10 & 30 & Existing & Yes & Yes & Not reported & & Style (2) & & & & \\
\hline $\begin{array}{l}\text { Geldens et al. } \\
\text { (2005), NL }\end{array}$ & $\begin{array}{l}\text { Which elements from the } \\
\text { analytic framework are visual } \\
\text { in the dialogues? What are } \\
\text { the central activities? Who } \\
\text { has the initiative? Is there a } \\
\text { relationship between the } \\
\text { duration and quality? Which } \\
\text { phases can be distinguished? }\end{array}$ & 7 & 4 & 22 & Existing & Yes (audio) & Yes & $\begin{array}{l}\text { Part (analysed } 1 \\
\text { with Kwalitan } \\
\text { software) }\end{array}$ & & Skills (5) & (b) Initiation & (a) $15-45 \mathrm{~min}$ & 5 & \\
\hline $\begin{array}{l}\text { Haggarty (1995), } \\
\text { UK }\end{array}$ & $\begin{array}{l}\text { In what respect were mentors } \\
\text { implementing their expected } \\
\text { role? }\end{array}$ & 5 & 10 & $\begin{array}{l}\text { Not } \\
\text { reported }\end{array}$ & New & Yes & Not reported & Part & & Skills (1) & $\begin{array}{l}\text { (b) Initiation and } \\
\text { participation }\end{array}$ & $\begin{array}{l}\text { (a) Total time all } \\
\text { dialogues is } \\
612.5 \mathrm{~min}\end{array}$ & & $\begin{array}{l}\text { Sources, } \\
\text { criteria } \\
\text { referred to } \\
\text { good } \\
\text { practice, } \\
\text { judgments }\end{array}$ \\
\hline $\begin{array}{l}\text { Harrison et al. } \\
\text { (2005), UK }\end{array}$ & $\begin{array}{l}\text { Exploring how a mentor } \\
\text { moves the beginning teacher } \\
\text { to greater independence and } \\
\text { professional autonomy (aim) }\end{array}$ & 8 & 8 & 38 & Existing & $\begin{array}{l}\text { Yes (audio and } \\
\text { video) }\end{array}$ & Yes & $\begin{array}{l}\text { Part (analysed } \\
\text { with QSR } \\
\text { NVivo } \\
\text { software }\end{array}$ & & Style (5) & & & 2 & \\
\hline $\begin{array}{l}\text { Hawkey (1998a), } \\
\text { UK }\end{array}$ & $\begin{array}{l}\text { Influence of the mentoring } \\
\text { relationship on mentors' } \\
\text { conceptions of their role and } \\
\text { on student teacher thinking } \\
\text { (aim) }\end{array}$ & 2 & 3 & 8 & New & Yes (audio) & Yes & Part & & Style (3) & & $\begin{array}{l}\text { (b) Reported, but } \\
\text { not in \% }\end{array}$ & & \\
\hline $\begin{array}{l}\text { Hawkey (1998b), } \\
\text { UK }\end{array}$ & $\begin{array}{l}\text { Understanding mentor } \\
\text { processes as they operate in } \\
\text { practice (concern) }\end{array}$ & 1 & 1 & 5 & $\begin{array}{l}\text { Existing and } \\
\text { new }\end{array}$ & Yes (audio) & Yes & Part & 4 & Skills (5) & & (a) $60 \mathrm{~min}$ & & \\
\hline Hughes (1998), UK & $\begin{array}{l}\text { To see to what extent } \\
\text { post-observational discourses } \\
\text { encouraged students to reflect } \\
\text { (intention) }\end{array}$ & 7 & 14 & 9 & Existing & Yes (audio) & Yes & $\begin{array}{l}\text { Part (analysed } \\
\text { with QST } \\
\text { NUD*IST } \\
\text { software }\end{array}$ & 6 & Skills (4) & $\begin{array}{l}\text { (a) Involvement } \\
\text { in text units }\end{array}$ & $\begin{array}{l}\text { (a) } 15-45 \mathrm{~min} \text {; } \\
\text { (b) } 69 \%\end{array}$ & & \\
\hline
\end{tabular}




\begin{tabular}{|c|c|c|c|c|c|c|c|c|c|c|c|c|c|c|}
\hline $\begin{array}{l}\text { Martin (1997), } \\
\text { Canada }\end{array}$ & $\begin{array}{l}\text { How do teachers work with } \\
\text { their mentees in the } \\
\text { classroom? How do they } \\
\text { challenge and support their } \\
\text { mentees and how is their } \\
\text { advice related to actual } \\
\text { mentees' practice? }\end{array}$ & 2 & 2 & $\begin{array}{l}\text { Not } \\
\text { reported }\end{array}$ & New & Yes (audio) & Not reported & Not reported & & Style (2) & & & & $\begin{array}{l}\text { The } \\
\text { classroom } \\
\text { tasks } \\
\text { assigned to } \\
\text { student } \\
\text { teachers }\end{array}$ \\
\hline $\begin{array}{l}\text { Orland-Barak and } \\
\text { Klein (2005), } \\
\text { Israel }\end{array}$ & $\begin{array}{l}\text { Exploring the nature, content } \\
\text { and type of interactions that } \\
\text { mentors attribute to their } \\
\text { mentoring conversations and } \\
\text { examining the way in which } \\
\text { these attributions are actually } \\
\text { realized in practice (aim) }\end{array}$ & 12 & 12 & 12 & New & Yes & Yes & $\begin{array}{l}\text { As a whole } \\
\text { (narrative) and } \\
\text { part }\end{array}$ & 4 & Skills (2) & & & & \\
\hline $\begin{array}{l}\text { Stanulis (1995), } \\
\text { USA }\end{array}$ & $\begin{array}{l}\text { How do classroom teachers } \\
\text { make sense of their role as } \\
\text { mentors in support of novices } \\
\text { as they learn to teach? }\end{array}$ & 5 & 5 & 6 & New & Yes (video) & Not reported & Not reported & & $\begin{array}{l}\text { Style (number } \\
\text { not reported) }\end{array}$ & & & & \\
\hline $\begin{array}{l}\text { Strong and Baron } \\
\text { (2004), USA }\end{array}$ & $\begin{array}{l}\text { How do mentor teachers } \\
\text { make pedagogical } \\
\text { suggestions and how do } \\
\text { beginning teachers respond? }\end{array}$ & 16 & 16 & 64 & New & Yes (audio) & Yes & Part & 5 & Skills (1) & & (a) $15-60 \mathrm{~min}$ & & \\
\hline $\begin{array}{l}\text { Timperley (2001), } \\
\text { New Zealand }\end{array}$ & $\begin{array}{l}\text { Changing the preoccupation } \\
\text { by school-based mentors with } \\
\text { immediate issues of practical } \\
\text { performance rather than } \\
\text { inquiry into or expansion of a } \\
\text { rationale of that performance } \\
\text { (aim) }\end{array}$ & 11 & 11 & 22 & New & Yes (audio) & Yes & $\begin{array}{l}\text { As a whole } \\
\text { (Likert scale) }\end{array}$ & & Skills (6) & & & & \\
\hline $\begin{array}{l}\text { Veenman and } \\
\text { Denessen (2001), } \\
\text { NL }\end{array}$ & $\begin{array}{l}\text { Do the coaches who } \\
\text { participated in the training } \\
\text { program actually implement } \\
\text { the target coaching skills? }\end{array}$ & $\begin{array}{l}35 \text { exp. gr.; } \\
22 \text { contr. gr. }\end{array}$ & $\begin{array}{l}35 \text { exp. gr.; } \\
22 \text { contr. gr. }\end{array}$ & 114 & Existing & Yes (audio) & $\begin{array}{l}\text { No, scored } \\
\text { from } \\
\text { audiotape }\end{array}$ & $\begin{array}{l}\text { As a whole } \\
\text { (Likert scale) }\end{array}$ & & Skills (3) & & & & \\
\hline $\begin{array}{l}\text { Wang et al. (2004), } \\
\text { USA and China }\end{array}$ & $\begin{array}{l}\text { How vary the foci and forms } \\
\text { of mentor-novice interactions } \\
\text { about teaching from one } \\
\text { context to another, and what } \\
\text { might be the consequences of } \\
\text { different interactions? }\end{array}$ & $\begin{array}{l}2 \text { (only } \\
\text { Chinese) }\end{array}$ & 2 & 4 & $\begin{array}{l}\text { New and } \\
\text { existing }\end{array}$ & $\begin{array}{l}\text { Yes (audio and } \\
\text { video) }\end{array}$ & Yes & Part & 3 & Skills (7) & $\begin{array}{l}\text { (a) 66-94\%; (b) } \\
\text { initiation }\end{array}$ & (a) $10-30 \mathrm{~min}$ & 3 & $\begin{array}{l}\text { Degree of } \\
\text { specificity } \\
\text { of speech } \\
\text { acts }\end{array}$ \\
\hline $\begin{array}{l}\text { Williams et al. } \\
\text { (1998), UK }\end{array}$ & $\begin{array}{l}\text { Improving our understanding } \\
\text { of the mentoring process } \\
\text { from the perspective of the } \\
\text { mentor teacher (aim) }\end{array}$ & 8 & 15 & 24 & Existing & Yes & Yes & Part & & $\begin{array}{l}\text { Style (3) and } \\
\text { skills (14) }\end{array}$ & & & & \\
\hline
\end{tabular}

${ }^{\mathrm{a}}$ For this review study relevant (abstraction of the) research question(s). If there is no explicit research question formulated, the relevant (abstraction of the) the aim, intention or concern of the study is reported. 


\section{References}

Achinstein, B., \& Barrett, A. (2004). (Re)Framing classroom contexts: How new teachers and mentor views diverse learners and challenges of practices. Teachers College Record, 106(4), 716-746.

Bennett, S. N., \& Carré, C. (Eds.). (1993). Learning to teach. London: Routhledge.

Bereiter, C., \& Scardamalia, M. (1993). Surpassing ourselves: An inquiry into the nature and implications of expertise. Chicago: Open Court.

Brouwer, C. N. (2007). Alternative teacher education in the Netherlands 2000-2005. A standards-based synthesis. European Journal of Teacher Education, 30(1), 21-40.

Bullough, R. V., \& Draper, R. J. (2004). Making sense of the failed triad-Mentors, university supervisors and positioning theory. Journal of Teacher Education, 55(5), 407-420.

Byra, M. (1994). Supervisory conferences: Promoting inquiry and reflection in preservice teachers. Paper presented at the annual meeting of the American Educational Research Association.

Caldwell, B. J., \& Carter, E. M. A. (1993). The return of the mentor teacher: Strategies of workplace learning. London: The Falmer Press.

Clinard, L. M., \& Ariav, T. (1998). What mentoring does for mentors: A cross-cultural perspective. European Journal of Teacher Education, 2l(1), 91-108.

Collison, J., \& Edwards, A. (1994). How teachers support student learning. In I. Reid, H. Constable, \& R. Griffiths (Eds.), Teacher education reform: Current research. London: Paul Chapman.

Copeland, W. D. (1982). Student teachers' preferences for supervisory approach. The Journal of Teacher Education, 33(2), 32-36.

De Jager, H., Mok, A. L., \& Sipkema, G. (2004). Grondbeginselen der sociologie [Basic principles of the sociology]. Groningen, NL: Wolters Noordhoff.

Dewey, J. (1933). How we think: A restatement of the relation of reflective thinking to the educative process. Boston: Heath.

Edwards, A. (1997). Guests bearing gifts: The position of student teachers in primary school classrooms. British Educational Research Journal, 23(1), 27-37.

Edwards, J., \& Green, K. (1999). Growth in coaching skills over a three-year period: Progress towards mastery. Paper presented at the annual conference of the American Educational Research Association.

Engelen, A. J. A. (2002). Coaching binnenstebuiten: Een onderzoek naar coaching van docenten door docenten [Coaching the other way around: A study about coaching of teachers by teachers]. Nijmegen: University Press.

Eraut, M. (2000). Non-formal learning and tacit knowledge in professional work. British Journal of Educational Psychology, 70, $113-136$.

Eraut, M. (2007). Learning from other people in the workplace. Oxford Review of Education, 33(4), 403-422.

Eraut, M., Alderton, J., Cole, G., \& Senker, P. (1998). Development of knowledge and skills in employment. Brighton, UK: University of Sussex Institute of Education, Education Development Building.

Feiman-Nemser, S. (2000). From preparation to practice: Designing a continuum to strengthen and sustain teaching. New York: Bank Street College of Education, Publications Office.

Feiman-Nemser, S. (2001). Helping novices learn to teach. Lessons form an exemplary support teacher. Journal of Teacher Education, 51(1), $17-30$.

Ferry, N. M., \& Ross-Gordon, J. M. (1998). An inquiry into Schön's epistemology of practice: Exploring links between experience and reflective practice. Adult Education Quarterly, 48(2), 98-112.

Field, B. (1994a). The past role of the teacher-Supervision as socialization. In B. Field \& T. Field (Eds.), Teachers as mentors: A practical guide (pp. 46-62). London: The Falmer Press.

Field, B. (1994b). The new role of the teacher-Mentor teachering. In B. Field \& T. Field (Eds.), Teachers as mentors: A practical guide (pp. 63-77). London: The Falmer Press.

Furlong, J., \& Maynard, T. (1995). Mentoring student teachers. The growth of professional knowledge. London: Routledge Falmer.

Gallego, M. A. (2001). Is experience the best teacher? The potential of coupling classroom and community-based field experiences. Journal of Teacher Education, 52(4), 312-324.

Geldens, J. J. M. (2007). Leren onderwijzen in een werkplekleeromgeving. Een meervoudige casestudy naar kenmerken van krachtige werkplekleeromgevingen voor aanstaande leraren basisonderwijs [Teacher Education in a workplace learning environment. A multiple case study to determine the distinctive characteristics of powerful workplace learning environments within primary teacher education]. Helmond: Kempellectoraat Hogeschool de Kempel.

Giebelhaus, C. R., \& Bowman, C. L. (2002). Teaching mentors: Is it worth the effort? Journal of Educational Research, 95(4), $246-254$.

Glickman, C. D. (1981). Developmental supervision: Alternative practices for helping teachers improve instruction. Alexandria, VA: Association for Supervision and Curriculum Development.

Glickman, C. D. (1985). Supervision of instruction: A development approach. Boston: Allyn \& Bacon.

Glickman, C. D., \& Bey, T. M. (1990). Supervision. In W. R. Houston (Ed.), Handbook of research on teacher education, a project of the association of teacher educators (pp. 549-566). Indianapolis: MacMillan.

Hatton, N., \& Smith, D. (1995). Reflection in teacher education: Towards definition and implementation. Teaching and Teacher Education, 11(1), 33-49.

Holland, P. E. (1989). Implicit assumptions about the supervisory conference: A review and analysis of literature. Journal of Curriculum and Supervision, 4(4), 362-379.

Holton, E. F., \& Baldwin, T. T. (2000). Making transfer happen: An action perspective on learning transfer systems. In E. F. Holton \& T. T. Baldwin (Eds.), Managing and changing learning transfer systems. Advances in Developing Human Resources, 2(4), 1-6.

Jacques, K. (1992). Mentoring in initial teacher education. Cambridge Journal of Education, 22(3), 337-350.

Kagan, D. (1992). Professional growth among preservice beginning teachers. Review of Educational Research, 62, $129-169$. 
Koetsier, C. P., \& Wubbels, J. T. (1995). Bridging the gap between initial teacher training and teacher induction. Journal of Education for Teaching: International Research and Pedagogy, 21(3), 333-346.

Korthagen, F. A. J. (1988). The influence of learning orientations on the development of reflective teaching. In J. Calderhead (Ed.), Teachers' professional learning (pp. 35-50). London: The Falmer Press.

Korthagen, F. A. J. (2001). A reflection on reflection. In F. A. J. Korthagen (Ed.), Linking practice to theory: The pedagogy of realistic teacher education (pp. 51-68). Mahwah, NJ: Lawrence Erlbaum.

Kwakman, K. (2003). Factors affecting teachers' learning participation in professional learning activities. Teaching and Teacher Education, 19, $149-170$.

Lave, J., \& Wenger, E. (1991). Situated learning: Legitimate peripheral participation. Cambridge: Cambridge University Press.

Luttenberg, J. (2002). Doceren en reflecteren. Over verbreding en verdieping van reflectie bij docenten [Teaching and reflecting. To broad and depth teachers' reflection]. VELON Tijdschrift voor lerarenopleiders, 23(1), 20-28.

Mantle-Bromley, C. (2003). The status of early theories of professional development school potential. In I. N. Guardarrama, J. Ramsey, \& J. L. Nath (Eds.), Forging alliances in community and thought. Research in professional development schools (pp. 3-30). Greenwich: Information Age.

McAlphine, L., Weston, C., Beauchamp, J., Weiseman, C., \& Beauchamp, C. (1999). Building a metacognitive model of reflection. Higher Education, $37,105-131$.

McLennan, N. (1995). Coaching and mentoring. Gower: Aldershot.

McNamara, D. (1995). The influence of student teachers' tutors and mentors upon their classroom practice: An exploratory study. Teaching and Teacher Education, 11(1), 51-61.

Merton, R. K. (1968). Social theory and social structure. New York: Free Press.

Mertz, N. T. (2004). What's a mentor, anyway? Educational Administration Quarterly, 40(4), 541-560.

Odell, S. J., Huling, L., Resta, V., Feiman-Nemser, S., Schwille, S. A., Bartell, C. A., et al. (2000). Framework for quality mentoring. In S. J. Odell \& L. Huling (Eds.), Quality mentoring for novice teachers (pp. 15-25). Washington, DC: Association of Teacher Educators.

Oosterheert, I., \& Vermunt, J. (2001). Individual differences in learning to teach: Relating cognition, regulation and affect. Learning and Instruction, $11,133-156$.

Orland, L. (2001). Reading a mentoring situation: One aspect of learning to mentor. Teaching and Teacher Education, 17, 75-88.

Pajak, E. (1993). Approaches to clinical supervision: Alternatives for improving instruction. Norwood, MA: Christopher-Gordon.

Rogers, R. R. (2001). Reflection in higher education. A concept analysis. Innovative Higher Education, 26(1), $37-57$.

Schein, E. (1978). Career dynamics: Matching individual and organizational needs. Reading, MA: Addison-Wesley.

Schön, D. A. (1987). Educating the reflective practitioner. San Francisco: Jossey-Bass.

Schön, D. A. (1983). The reflective practitioner: How professionals think in action. New York: Basic Brooks.

Smith, P. J. (2003). Workplace learning and flexible delivery. Review of Educational Research, 73(1), 53-58.

Stanulis, R. N., \& Russell, D. (2000). "Jumping in": Trust and communication in mentoring student teachers. Teaching and Teacher Education, 16, $65-80$.

Stijnen, P. J. J. (2003). Leraar worden: "Under construction"? Over lerarentekorten en afstandsonderwijs voor de opleiding tot leraar [Become a teacher: "Under construction"? About teacher shortages and distance courses for teacher education]. Oratie. Heerlen, NL: Open Universiteit.

Sundli, L. (2007). Mentoring-A new mantra for education? Teaching and Teacher Education, 23, 201-214.

Turner, M. (1993). The role of mentors and teacher tutors in school-based teacher education and induction. British Journal of In-Service Education, $19,36-45$.

Van Eekelen, I. M. (2005). Teachers' will and way to learn. Studies on how teachers learn and their willingness to do so. Dissertation. Maastricht.

Van IJzendoorn, M. H. (1998). Meta-analysis in early childhood education: Progress and problems. In B. Spodek, O. N. Saracho, \& A. D. Pellegrini (Eds.), Issues in early childhood educational research (pp. 156-176). New York: Teacher College Press.

Vásquez, C. (2004). "Very carefully managed": Advice and suggestions in post-observation meetings. Linguistics and Education, $15,33-58$.

Vonk, J. H. C. (1996). Conceptualizing the mentoring of beginning teachers. Paper presented at the annual conference of the American Educational Research Association.

Waite, D. (1992). Supervisors talk: Making sense of conferences from an anthropological linguistic perspective. Journal of Curriculum and Supervision, 7(4), 349-371.

Waite, D. (1993). Teachers in conference: A qualitative study of teacher-supervisor face-to-face interactions. American Educational Research Journal, 30(4), 675-702.

Wang, J. (2001). Contexts of mentoring and opportunities for learning to teach: A comparative study of mentoring practice. Teaching and Teacher Education, 17, 51-73.

Zeichner, K., \& Listen, D. (1985). Varieties of discourse in supervisory conferences. Teaching and Teacher Education, 1(2), $155-174$.

Zelditch, M. (1990). Mentor roles. In Proceedings of the 32nd annual meeting of the Western Association of Graduate Schools (p. 11).

\section{References to publications in the review (26 studies)}

Ben-Peretz, M., \& Rumney, S. (1991). Professional thinking in guided practice. Teaching and Teacher Education, 7(5/6), 517-530.

Borko, H., \& Mayfield, V. (1995). The roles of the cooperating teacher and university supervisor in learning to teach. Teaching and Teacher Education, $11,501-518$.

Coulon, S. C. (1994). The effect of post teaching conferences on the instructional behaviours of student teachers. Paper presented at the Annual Meeting of the American Educational Research Association.

Crasborn, F. A. J., Hennissen, P. P. M., \& Brouwer, C. N. (2005). Teacher coaches' dialogues with prospective teachers. A study of transfer of training. Paper presented at the biennial conference of the European Association for Research on Learning and Instruction. 
Dunn, T. G., \& Taylor, C. A. (1993). Cooperating teacher advice. Teaching and Teacher Education, 9(4), 411-423.

Dunne, E., \& Bennett, N. (1997). Mentoring processes in school-based training. British Educational Research Journal, $23,225-237$.

Edwards, A., \& Collison, J. (1996). Mentoring and developing practice in primary schools: Supporting student teacher learning in schools. Buckingham: Open University Press. [Chapter 3].

Edwards, A., \& Protheroe, L. (2004). Teaching by proxy: Understanding how mentors are positioned in partnerships. Oxford Review of Education, 30(2), 183-197.

Evertson, C. M., \& Smithey, M. W. (2001). Mentoring effects on protégé classroom practice. Journal of Educational Research, 93(5), $294-304$.

Feiman-Nemser, S., \& Parker, M. B. (1990). Making subject matter part of the conversation in learning to teach. Journal of Teacher Education, 41(3), 32-43.

Feiman-Nemser, S., Parker, M. B., \& Zeichner, K. (1992). Are mentor teachers teacher educators? Research Project 92-11. East Lansing, Michigan: The National Center for Research on Teacher Learning.

Franke, A., \& Dahlgren, L. O. (1996). Conceptions of mentoring: An empirical study of conceptions of mentoring during the school-based teacher education. Teaching and Teacher Education, 12(6), 627-641.

Geldens, J. J. M., Popeijus, H., Peters, V., \& Bergen, Th. (2005). Mentoring met kwaliteit als krachtig kenmerk van werkplekomgevingen voor aanstaande leraren. Analyseresultaten van mentoringsgesprekken [The quality of mentoring as a feature of effective workplace environments for prospective teachers. Analysing results of mentoring dialogues]. Paper presented at the Onderwijs Research Dagen.

Haggarty, L. (1995). The use of content analysis to explore conversations between school teacher mentors and student teachers. British Educational Research Journal, 21(2), 183-197.

Harrison, J., Lawson, T., \& Wortley, A. (2005). Mentoring the beginning teacher: Developing professional autonomy through critical reflection on practice. Reflective Practice, 6(3), 419-441.

Hawkey, K. (1998a). Mentor pedagogy and student teacher professional development: A study of two mentoring relationships. Teaching and Teacher Education, 14(6), 657-670.

Hawkey, K. (1998b). Consultative supervision and mentor development: An initial exploration and case study. Teachers and Teaching: theory and practice, 4(2), 331-348.

Hughes, M. (1998). Developing the use of qualitative analysis to describe and explore the effectiveness of post-observational discourse between school-based mentors and students in teacher education. Paper presented at the European conference on educational research.

Martin, D. (1997). Mentoring in ones own classroom: An exploratory study of contexts. Teaching and teacher education, 13(2), $183-198$.

Orland-Barak, L., \& Klein, S. (2005). The expressed and the realized: Mentors' representations of a mentoring conversation and its realization in practice. Teaching and teacher education, 21, 379-402.

Stanulis, R. N. (1995). Classroom teachers as mentors: Possibilities for participation in a professional development school context. Teaching and Teacher Education, 11(4), 331-344.

Strong, M., \& Baron, W. (2004). An analysis of mentoring conversations with beginning teachers: Suggestions and responses. Teaching and Teacher Education, 20, 47-57.

Timperley, H. (2001). Mentoring conversations designed to promote student teacher learning. Asia-Pacific Journal of Teacher Education, 29(2), 111-123.

Veenman, S., \& Denessen, E. (2001). The coaching of teachers: Results of five training studies. Educational Research and Evaluation, 7(4), $385-417$.

Wang, J., Strong, M., \& Odell, S. J. (2004). Mentor-novice conversation about teaching: A comparison of two U.S. and two Chinese cases. Teacher College Record, 106(4), 775-813.

Williams, E. A., Butt, G. W., Gray, C., Leach, S., Marr, A., \& Soares, A. (1998). Mentors' use of dialogue within a secondary initial teacher education partnership. Educational Review, 3(50), 225-239. 